(1)

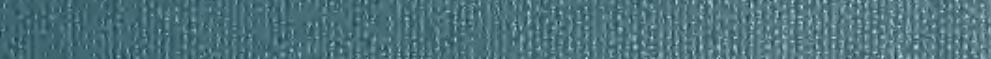
(6)

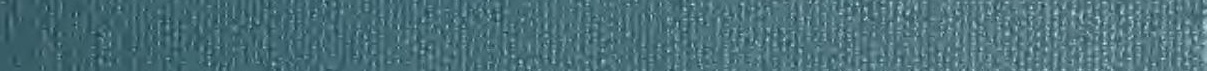
i. 5. (4) Hon

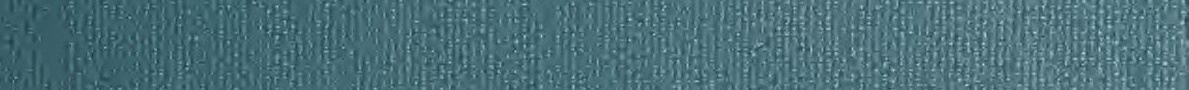
$180 \mathrm{c}$. Se I. $=$

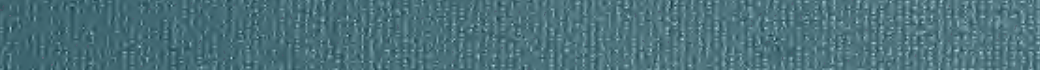

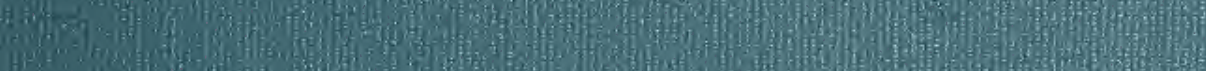

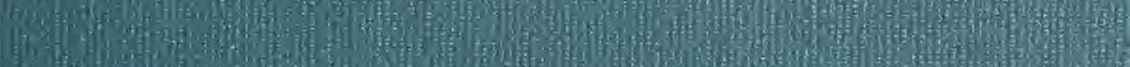

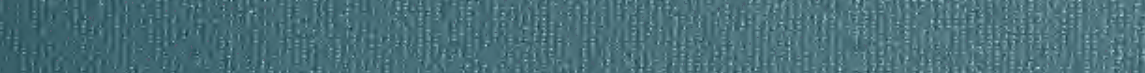

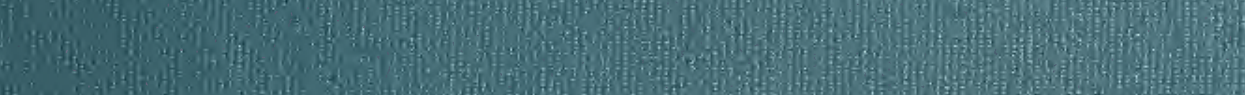
If

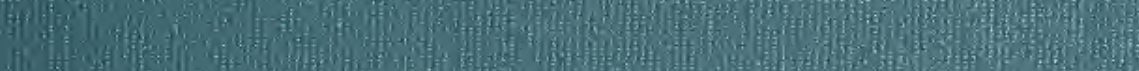
4. (1) 5. Hof an

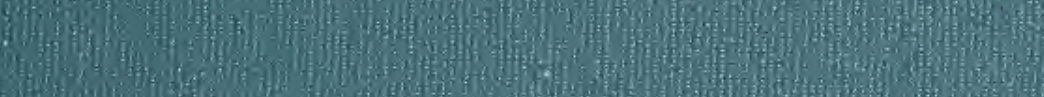

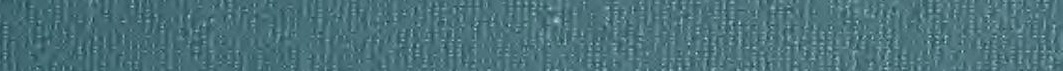

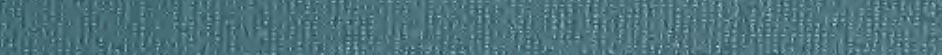
An (1.6. Sto H.

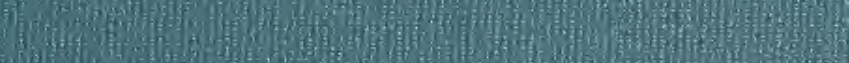
160.

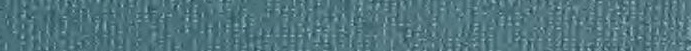
4han 3.

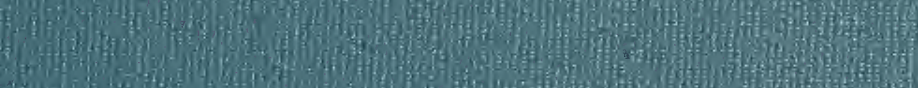

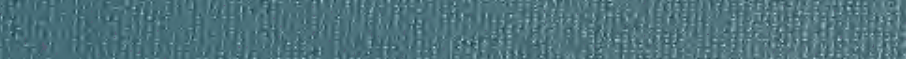
(Wha (30. W. (1)

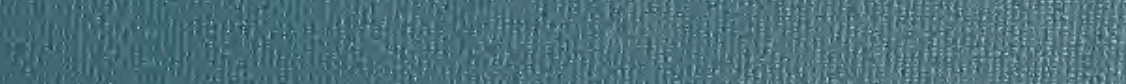
Fun 

Digitized by the Internet Archive in 2011 with funding from LYRASIS members and Sloan Foundation 



\section{THE GYPSY MOTH}

W. E. BRITTON

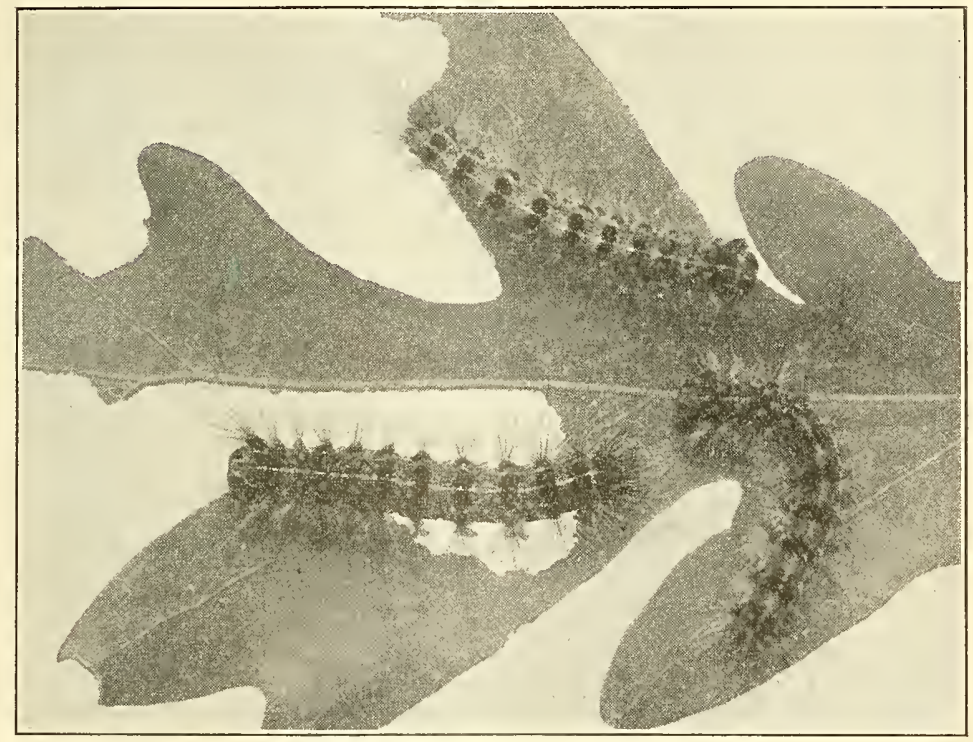

\section{Cammecticut}

\section{Agricultural Experiment Station}

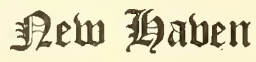


BOARD OF CONTROL

His Excellency, Governor Wilbur L. Cross, ex-officio, President

Elijah Rogers, Vice-President .......................... Southington

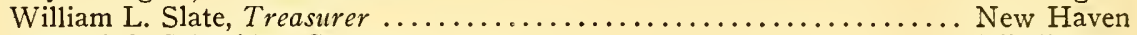

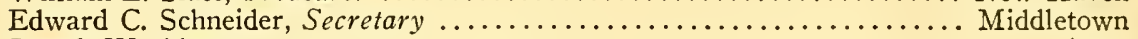

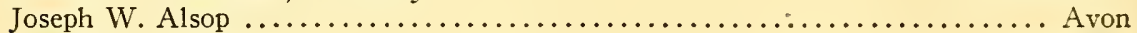

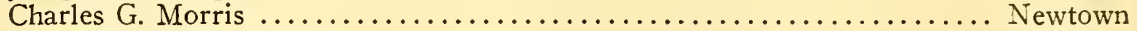

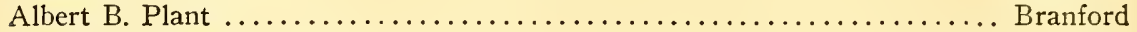

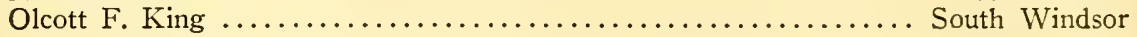

STAFF

Administration.

Analytical

Chemistry.

Biochemistry.

Botany.

Entomology.

Forestry.

Plant Breeding.

Soils.

Tobacco Substation at Windsor.
William L. Slate, B.Sc., Director.

Miss L. M. Brautlecht, Bookkeeper and Librarian.

Miss Katherine M. Palmer, B.Litt,, Editor.

G. E. GrahaM, In Charge of Buildings and Grounds.

E. M. Bailey, Ph.D., Chemist in Charge.

C. E. SHepard

OWEN L. NOLAN

HarRY J. Fisher, Ph.D. Assistant Chemists.

W. T. Mathis

David C. WALDEN, B.S.

V. L. Churchill, Sampling Agent.

Mrs. A. B. Vosburgh, Secretary.

H. B. VICKERY, Рн.D., Biochemist in Charge.

Lafayette B. Mendel, PH.D., Research Associate (Yale University).

George W. Pucher, Ph.D., Assistant Biochemist.

G. P. Cinnton, Sc.D., Botanist in Charge.

E. M. Stodda Rd, B.S., Pomologist.

Miss Florence A. MCCormick, PH.D., Pathologist.

A. A. Dunlap, PH.D., Assistant Mycologist.

A. D. McDonnell, General Assistant.

Mrs. W. W. KeISEy, Secretary.

W. E. Britton, Ph.D., D.Sc., Entomologist in Charge, State Entomologist. B. H. WALDEN, B.Agr.

II. P. ZAPPE, B.S.

Philip Garman, PH.D. $\quad$ Assistant Entomologists.

Roger B. Friend, Ph.D.

NEELY TURNER, M.A.

JoHN T. Ashworth, Deputy in Charge of Gipsy Moth Control.

R. C. Botsford, Deputy in Charge of Mosquito Elimination.

J. P. Jornson, B.S., Deputy in Charge of Japanese Beetle Control.

$\left.\begin{array}{l}\text { Miss Helen A. Hulse } \\ \text { Miss Betty Scoville }\end{array}\right\}$ Secretaries.

WALTER O. Filley, Forester in Charge.

H. W. Hicock, M.F., Assistant Forester.

I. E. Riley, JR., M.F., In Charge of Blister Rust Control.

Miss Pauline A. Merchant, Secretary.

Donald F. Jones, Sc.D., Geneticist in Charge.

W. Ralpi Singleton, Sc.D., Assistant Geneticist.

Lawrence C. Curtis, B.S., Assistant.

M. F. Morgan, PH.D., Agronomist in Charge.

H. G. M. JAcobson, M.S., Assistant Agronomist.

Herbert A. Lunt, PH.D., Assistant in Forest Soils.

Dwight B. Downs, General Assistant.

Miss Geraldine Everett, Secretary.

Paul J. Anderson, Ph.D., Pathologist in Charge.

T. R. SivanBack, M.S.. Agronomist.

O. E. Street, PH.D., Plant Physiologist.

Miss Dorothy Lenard, Secrctary. 


\section{CONTENTS}

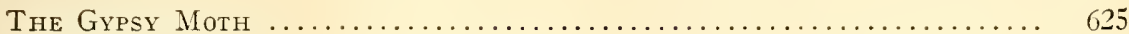

Distribution Abroad and History in America ................... 625

The Gypsy Moth in. Other Countries .................... 625

Appearance and Spread in the United States .................. 625

Discovery and Spread in Connecticut ..................... 627

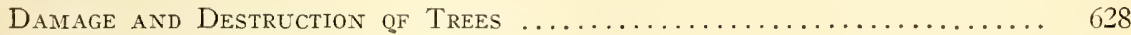

Food Plants and Injury $\ldots \ldots \ldots \ldots \ldots \ldots \ldots \ldots \ldots \ldots \ldots \ldots \ldots \ldots \ldots \ldots \ldots$

Defoliation of Trees ........................................ 629

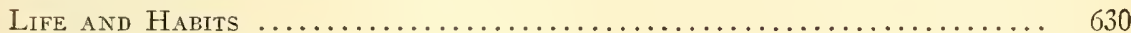

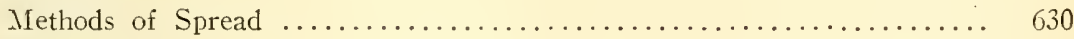

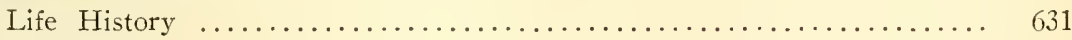

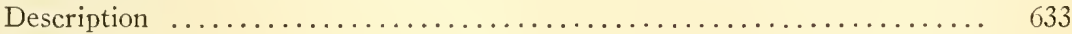

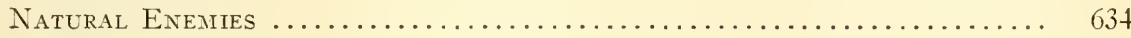

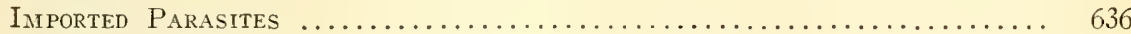

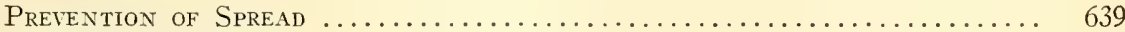

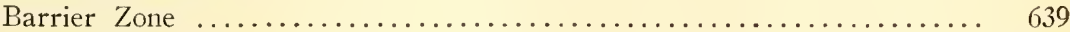

Quarantine Restrictions ............................ 639

Control Measures $\ldots \ldots \ldots \ldots \ldots \ldots \ldots \ldots \ldots \ldots \ldots \ldots \ldots \ldots \ldots \ldots \ldots \ldots \ldots \ldots$

Scouting and Creosoting Egg-Clusters $\ldots \ldots \ldots \ldots \ldots \ldots \ldots \ldots \ldots \ldots \ldots \ldots \ldots \ldots \ldots \ldots$

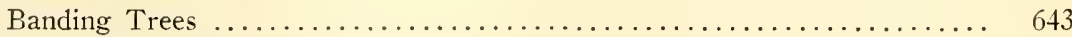

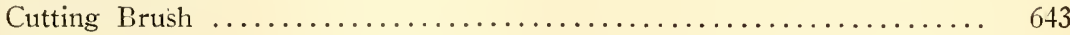

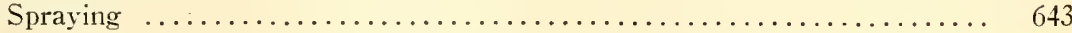

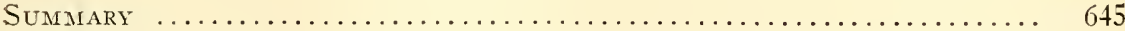

The cover cut (Figure 76 ) shows gypsy moth caterpillars feeding on an oak leaf. About natural size. 


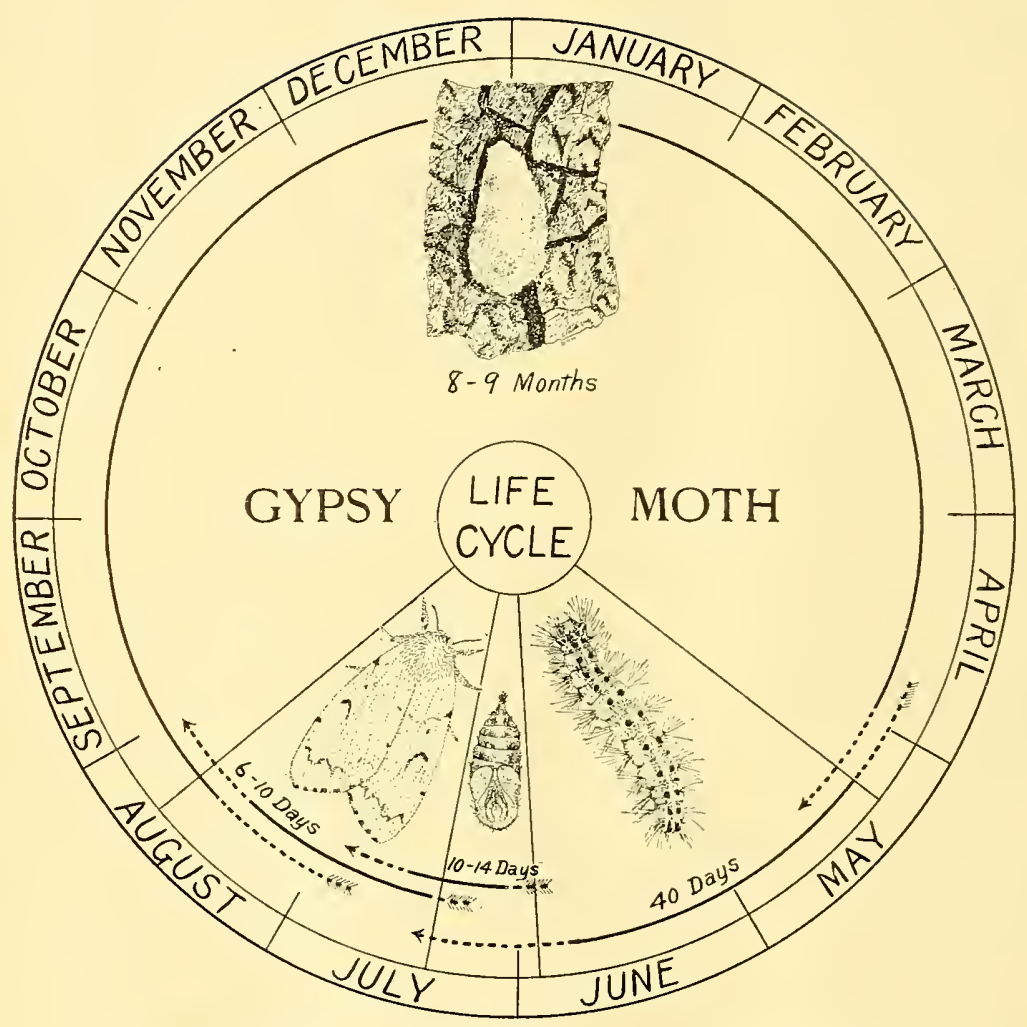

FIGURE 77. Diagram showing life history of gypsy moth. 


\section{THE GYPSY MOTH*}

\section{Porthetria dispar Linn.}

\section{W. E. Britton, State Entomologist}

The gypsy moth, one of the hardiest and most destructive insects known, came to Connecticut by way of Massachusetts. For nearly 45 years that state has been engaged in an attempt to control the pest. In spite of these early efforts, however, the moth kept on spreading and soon reached other states where it has also caused great damage. Of course in the early days of the infestation our modern effective control methods had not been developed. It was necessary to try new measures and note results.

Since 1906, when Congress first made an appropriation for this work, the Federal Bureau of Entomology has coöperated with the various states in suppressing the gypsy moth. It was in the same year (1906) that Connecticut first used state funds for this purpose, and up to June 30 , 1934 , about $\$ 806,504.87$ has been expended by the state forces. This sum, together with federal appropriations including emergency relief funds, makes a total of more than $\$ 2,000,000$ that has been expended officially for the control of the gypsy moth in Connecticut. Since 1891 the states, the Federal Government of the United States and the Dominion of Canada have spent upward of $\$ 41,000,000$ in all the infested areas.

\section{DISTRIBUTION ABROAD AND HISTORY IN AMERICA}

\section{The Gypsy Moth in Other Countries}

The gypsy moth occurs in central and southern Europe, northern Africa, and throughout southern and central Asia, including Japan and Ceylon. On the European continent the insect becomes abundant at intervals and causes great damage in certain areas. In general, however, it is held in check by its natural enemies and is nowhere such a serious pest as it has proven to be in this country. It is now considered a rare insect in England. As most of the earlier collections contained plenty of examples of the gypsy moth and the more recent ones do not, it is fair to assume that it was formerly rather abundant there.

\section{Appearance and Spread in the United States}

According to the best obtainable information, the gypsy moth was first brought into this country in 1869 , or thereabouts, by Mr. L. Trouvelot,

\footnotetext{
*A revision of Bulletin 186, with much new matter added and some portions entirely rewritten.
} 
an artist and astronomer who was interested in silk culture. In order to overcome a wilt disease or "flacherie" then playing havoc in some silk worm establishments, he tried to cross the silk worm with certain other species to obtain a hardier or more resistant race of silk worms. Among other silk spinning caterpillars in their various stages, which he imported from France for this purpose, were some egg-masses of the gypsy moth. Some of the caterpillars escaped accidentally from the breeding cages at his home, 27 Myrtle Street, Medford, Mass., and though he searched for them and published a notice at the time, the affair was soon forgotten. The insect was not seen for years, but by 1889 had become a serious pest defoliating many trees in this same locality.

The town of Medford first raised a sum of money for its control, and in 1890 the State Legislature made its first appropriation for moth work. At first only a small area was infested, and had the knowledge and experience which we now possess then been available, the pest might perhaps have been exterminated. But methods had to be worked out, men trained, the insect studied, and as many of the earlier methods finally were shown to be ineffective, the insect was not eradicated. Finally, after 10 years, the Massachusetts legislature in 1900 refused to make further appropriations and the state suppression work ceased. At that time the infested area covered 359 square miles in the vicinity of Boston.

For five years no state work was carried on, though many private owners and probably some municipalities controlled the pest on the land under their jurisdiction. In 1905 the gypsy moth had spread and multiplied and become such a nuisance that state control work was resumed and has since been continued. But by that time the infested area covered 2,224 square miles instead of 359, and extended from beyond the New Hampshire line south to Buzzard's Bay, and westward as far as Marlborough. A large colony had also become established at Providence, R. I. It had no doubt spread considerably beyond these limits, for it was soon found in New Hampshire and later in Connecticut and in Maine.

At the present time, the gypsy moth occurs in all of the New England States, but does not infest their entire area. The infested area includes: The eastern two-thirds of Connecticut, the whole of Rhode Island, all of Massachusetts except Berkshire County in the western part, the southwestern third of Maine, all of New Hampshire except a few towns in the northernmost portion equivalent to about one-third of Coos County, and the eastern half of Vermont, except Orleans and northern Essex counties in the north. Separate infestations are also present on Long Island in New York, in Morris County in New Jersey, and in the vicinity of Scranton and Wilkes-Barre in Pennsylvania. These isolated infestations will probably be eradicated as many others have been, in the course of the attempt at official control.

Among more than 400 infestations that have been completely wiped out, only a few can be mentioned here. Connecticut: Greenwich, New Haven, Seymour, Stonington, Wallingford and Woodbridge (Stonington afterwards again became infested); Ohio: near Cleveland; Pennsylvania: Loretto; New Jersey: Rutherford; New York: Brooklyn, Chesterfield, Geneva, Greenport, L. I., Moriah and Mount Kisco; Vermont: Alburg, 
Bennington, Benson, Castleton, Danby, Essex, Fairfield, Fair Haven, Ferrisburg, Ira, Leicester, Pittsford, Rutland and Salisbury.

In addition to the infestations listed above, a great many colonies have been eradicated, but later the areas became reinfested. Also many small infestations have been uprooted in the barrier zone.

\section{Discovery and Spread in Connecticut}

The presence of the gypsy moth in Connecticut was discovered in July, 1905, when two female moths were taken and two males seen in Stonington, by Ernst Frensch, a local collector of insects. Later a few egg-clusters were noticed. Mr. Frensch communiçated with this Station in February, 1906, and the writer visited him and saw his specimens and the eggclusters.

Apparently the center of the infestation was in some low brush around a pond near the velvet mill on the eastern side of the village. These eggclusters were soon creosoted and the brush cut and burned. Later eggclusters were discovered on some of the apple trees and shade trees in the near vicinity and scattered throughout the village. Altogether, less than a square mile seemed to be infested.

In 1906, 73 egg-clusters, 10,000 caterpillars and 47 pupae were destroyed. In 1907, 118 egg-clusters, nearly 3,000 caterpillars and 200 pupae were destroyed. The numbers decreased each year until 1911, when only three egg-clusters were found. Although careful scouting was done in Stonington in 1912 and early in 1913, there were no traces of the gypsy moth until summer, when five caterpillars and one pupa were discovered. It seemed to be a reinfestation and this view was later confirmed by federal scouts, who found scattered egg-clusters in nearly all of the eastern border towns of the State during the following winter. The infestation in Stonington was evidently eradicated wholly by creosoting egg-clusters, seeking and crushing caterpillars and pupae under burlap bands, in cavities and other protected places. Spraying with poison, as now practiced, was attempted only in a small way.

Another infestation was discovered in December, 1909, in the village of Wallingford. More than 8,000 egg-clusters, nearly 9,000 caterpillars, and 100 pupae were destroyed there during the first year. The numbers were reduced rapidly, and in 1913 only two egg-clusters and three caterpillars could be found. No gypsy moth infestation has occurred there since. Altogether less than a square mile of territory was infested, and the control measures practiced were creosoting egg-clusters, pruning and scraping trees, filling and covering cavities, cutting and burning worthless trees and brush, banding trees with burlap and with tanglefoot, and spraying trees with lead arsenate.

It is uncertain how the gypsy moth reached Wallingford, but probably egg-clusters were carried there unnoticed on a crate or packing box. The center of infestation seemed to be just north of Center Street, in the rear of some stores that had received many shipments of goods from eastern Massachusetts. In later years several localities in the town of Wallingford became infested when the insect spread westward. 
In May, 1913, windspread must have occurred along the Rhode Island border. The following winter the gypsy moth appeared in 10 towns, including most of those adjoining Rhode Island, and, in some cases, in the second tier of towns as well.

In 1915 the pest was found in 10 additional towns, making 20 altogether. By 1917 this number had increased to 22, and by 1918, to 29 towns, all in New London and Windham counties. In 1920, and possibly in 1921, windspread carried the pest into other counties, adding 35 towns to the list, and making in all 64 infested by the gypsy moth.

In 1923, when the control or barrier zone was established, there were 100 Connecticut towns infested. Since then the pest has invaded a few more. However, with the present system of careful and thorough work in the barrier zone, only slight future changes may be expected in the relationship between infested and non-infested towns. At this writing, 60 are in the barrier zone or southwest of it, and 109 are in the quarantined area, although many of them are only slightly infested. With the prospect of large federal allotments of relief funds and additional CCC camp work on gypsy moth control, there is a possibility that some of the westernmost towns in the quarantined area may soon be freed from infestation and quarantine.

\section{DAMAGE AND DESTRUCTION OF TREES}

\section{Food Plants and Injury}

The caterpillars of the gypsy moth damage trees, shrubs and other plants by stripping them of their leaves. Formerly it was supposed that they would attack almost any kind of foliage, ash being perhaps the most nearly immune of any of our broad-leaved deciduous trees. In the publication, "The Gypsy Moth," by Forbush and Fernald, is given a list of several hundred food plants, containing nearly all the common cultivated ones. But more recent investigations at the parasite laboratory, Melrose Highlands, Mass., conducted under the direction of Mr. A. F. Burgess, show that the caterpillars in their first and second stages are not able to live on some of these plants even though they may feed on them in later stages of development. For instance, though the caterpillars in their later stages will feed upon pine, and have killed large areas of pine mixed with hard wood in Massachusetts, they must have some deciduous foliage for food in their first and second larval stages. Considering the matter from this standpoint, it seems quite possible to cut out all other growth, leaving solid stands of pine or other conifers which, with only slight protection, may escape destruction. By the use of tanglefoot on the trunks of the trees around the margins of such an area, little damage will result.

The caterpillars are partial to fruit trees, willow, oak, poplar and rose. But when they are abundant, food becomes increasingly scarce and they will feed upon a great many different trees and plants. 


\section{Defoliation of Trees}

Wherever gypsy moth infestations are permitted to build up without artificial check, as frequently occurs in undiscovered woodland colonies, severe defoliation or "stripping" of the trees may take place. Extensive defoliation has occurred at various times in the past in eastern Massachusetts and many acres of woodland trees were killed. In 1918, certain woodland areas near the base of Cape Cod were wholly or partially defoliated. and this condition has been more or less constant throughout the generally infested area in Maine, Massachusetts and New Hampshire.

Even in more recent years extensive stripping has occurred in the New England States. In 1926, about 70,000 acres, and in 1927, 142,000 acres were completely or partially defoliated. In 1928, the area increased

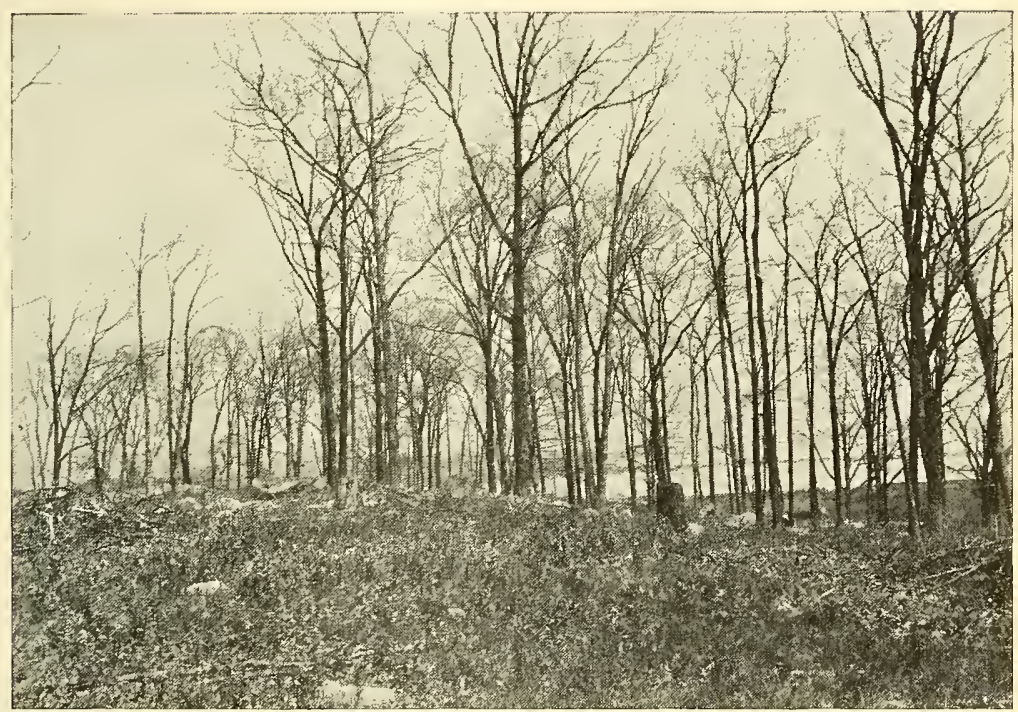

FIGURE 78. About 30 acres of woodland were stripped by gypsy moth caterpillars near Groton Long Point. Photographed July 10, 1933.

to 262,000 acres, and for the first time defoliation was found in Connecticut. The stripped areas were chiefly in Maine, Massachusetts, New Hampshire, and small sections in Rhode Island and Connecticut. In 1932, a few oak trees were stripped in Brooklyn and Killingly. In July, 1933, just after the close of the spraying season, a gypsy moth infestation was discovered near Groton Long Point, where the large merchantable trees on 30 or more acres of land had been partially or completely defoliated.

Figure 78 shows some of these stripped trees. Soon after the females finished laying eggs, clean-up measures began. Altogether, 286.66+ eggclusters were creosoted in this place. Some of the trees stripped in 1933 failed to put out leaves, and in 1934 many of them had died as shown in Figure 79. 


\section{LIFE AND HABITS}

\section{Methods of Spread}

As the insect passes about three-quarters of its life cycle, including the winter, in the egg stage, there is a long period from late July until the following May when the egg-clusters may be transported on packing boxes, crates, freight cars, vehicles, nursery stock, lumber, quarry, or other products, which have remained for a time in July or August in the infested region. This is especially true if these products have been stored, stacked, or allowed to stand where gypsy moths were abundant at the time when the eggs were laid. The egg-clusters are seldom noticed or recognized by the men handling these materials, and may be shipped

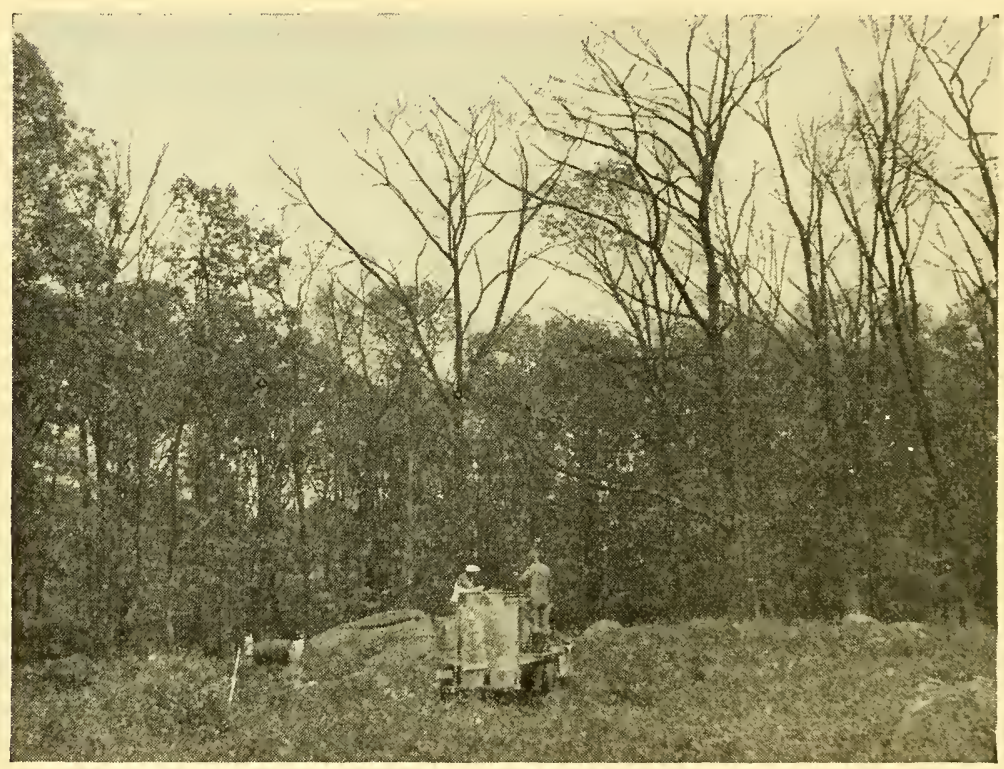

FigURE 79. View of trees at Groton, defoliated by gypsy moth caterpillars in 1933. Some of these trees did not leaf out in 1934.

Photographed June 14, 1934.

long distances into various states. This is the reason for establishing a quarantine, thus preventing all shipments going out, unless inspected and certified by a federal inspector. This method of spread will probably account for the isolated infestations at Stonington and Wallingford and for most of those in other states.

The caterpillars when nearly grown, and especially if very numerous, crawl about in search of food or a place in which to pupate. They sometimes board trains or other vehicles and may be transported by these means. The insect may also be carried from place to place in the pupa and adult stages. But there is less danger of spread then because the females do 
not fly, the pupae are usually in holes or protected places and because these stages in the life cycle are short.

Windspread is probably accountable for most of the extension of the large area of infestation which has been more rapid toward the north and east than in other directions. When the caterpillars first hatch from the eggs, they are, of course, very small and are covered with hairs, some of which are bulbous and known as aërostatic hairs. Whether or not this is their real function, it is true that these first stage caterpillars are carried long distances by strong winds occurring at this time. Several years ago Mr. Burgess had a large screen placed on the Isles of Shoals, seven miles away from the nearest infested trees in New Hampshire. It was covered with tanglefoot and caught several young caterpillars. According to the federal men, windspread explains the scattered infestations through eastern Connecticut in the spring of 1913. Of course, if the wind blows toward the center of the infested area no harm will result, but if it blows outward, the area may be greatly extended.

A more extensive windspread occurred in 1920 and possibly in 1921, carrying the pest into Tolland, Hartford, Litchfield, Middlesex and New Haven counties, more than doubling the number of infested towns in Connecticut.

\section{Life History}

The young caterpillars, hatching from the eggs about May 1, feed and hide upon the leaves, spinning down on silken threads when disturbed. They usually feed at night and often rest on the under side of the leaves during the day, where their presence is apt to be overlooked. They molt five or six times and gradually increase in size, reaching maturity early in July. Caterpillars molting five times usually develop into males, and those molting six times become females, according to Mosher and Webber*, who have carried on many experiments and observations at the Gypsy Moth Laboratory at Melrose Highlands, Mass. During this entire larval period, the caterpillars are hairy, dark in general color and some show a predominating tint of brown while others are gray.

There is much variation in size, the largest caterpillars being nearly three inches long (probably molting six times); most of them, however, are between two and two and one-half inches. From the time they are half-grown, they hide during the day in crevices in the bark, in cavities, or in some other dark place, presumably to escape bright sunlight, and are found on the leaves chiefly at night. When fully grown they crawl about to find a protected place in which to pupate. The pupa stage lasts from ten days to two weeks, when the adult emerges.

The male moth is generally brown in color and flies about even in the day time. The female is nearly white, with rather inconspicuous cross markings of brown and black, and is larger than the male. The female has a heavy body and does not fly but rests on the trunk or branches of trees, sides of buildings and walls, and in such places she lays her eggs. Figure 83. The adults take no food and live only a short time.

*Journal Economic Entomology, Vol. 7, page 368, 1914. 


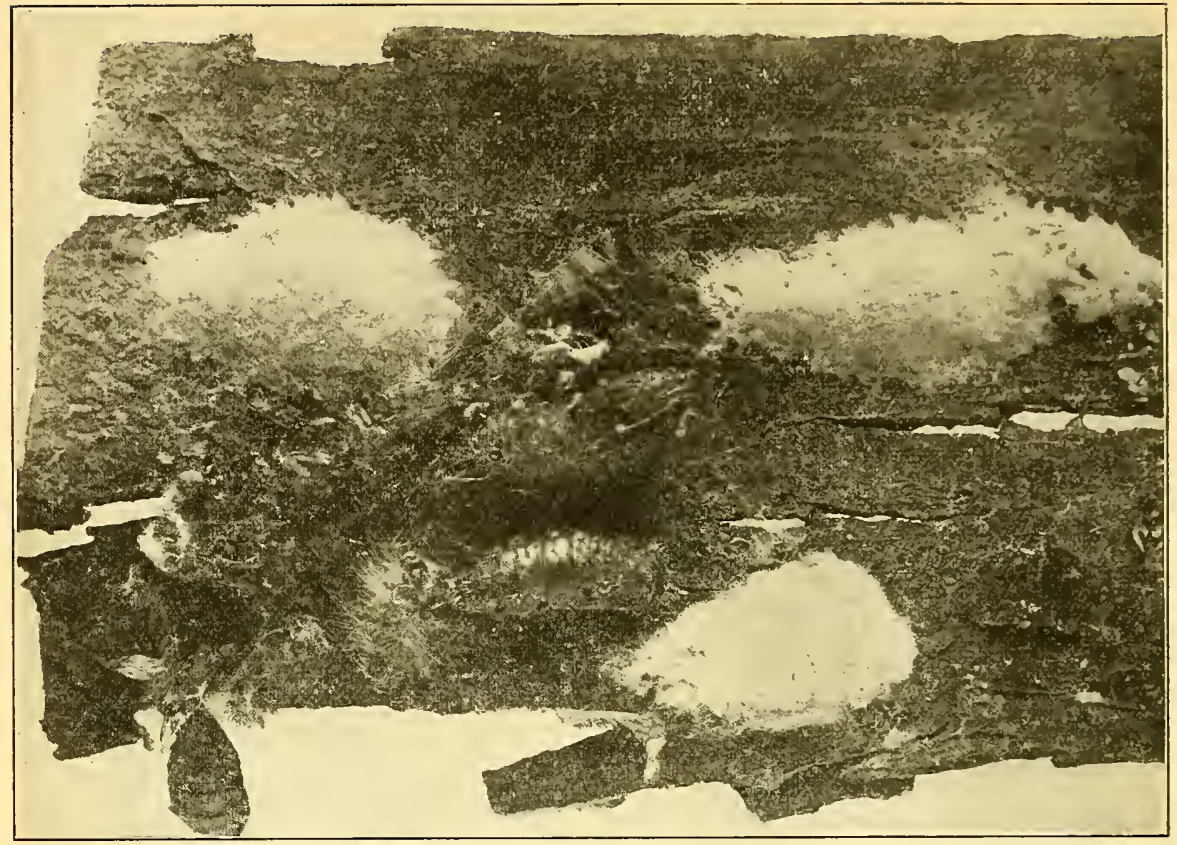

Figure 80. Egg-clusters and pupae on inside of loose hickory bark.

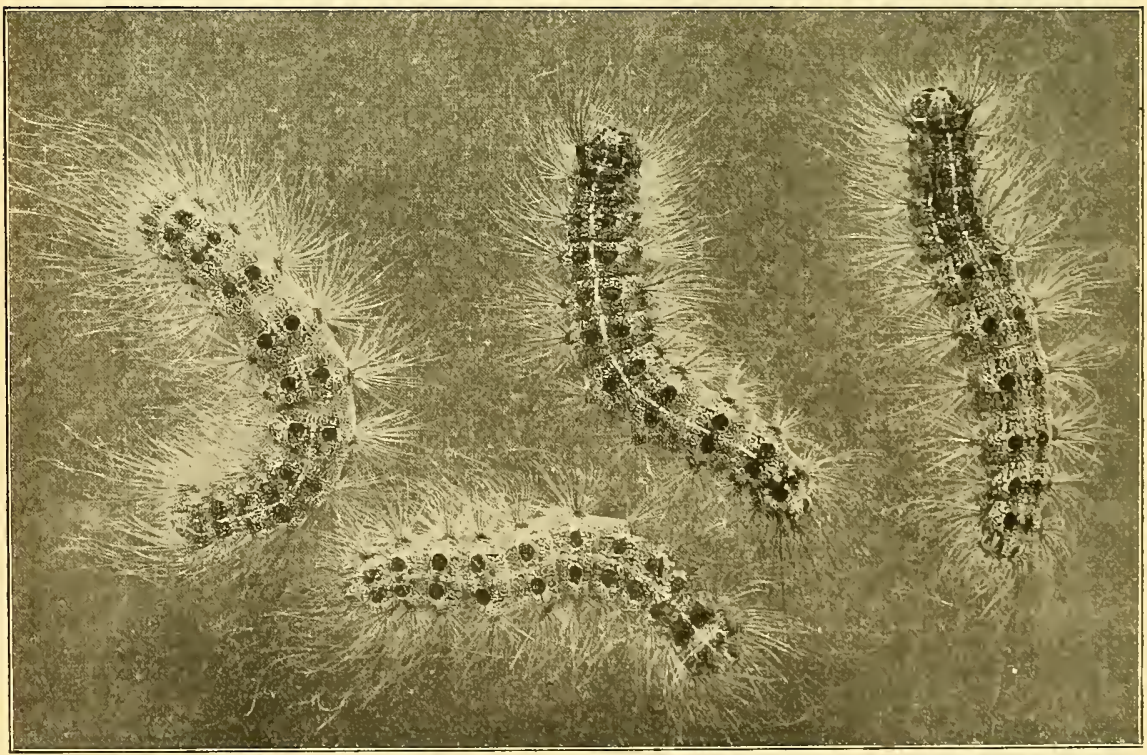

Figure 81. Gypsy moth caterpillars. Natural size. 
It is in the egg stage that most of the time is spent, the eggs being found from August until the following May, a period of nine months.

\section{Description}

Egg. The egg is globular, white or transparent, and slightly more than $1 \mathrm{~mm}$. in diameter. An average of between 400 and 500 eggs are laid together in a cluster and covered with the buff hairs from the body of the moth. The egg-clusters vary greatly in size and shape, but roughly speaking they are oval, about two-thirds as broad as long, and look and feel like a piece of chamois skin. Some large egg-clusters are two inches or more in length, and small ones may be not more than half an inch,

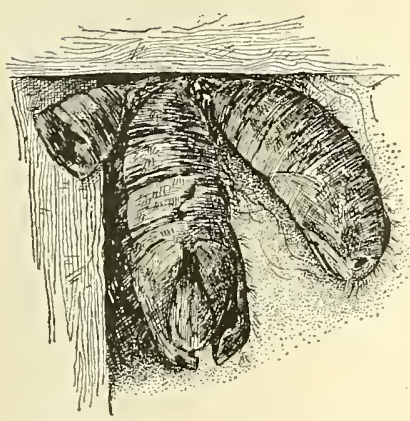

Figure 82. Old pupa skins under fence rail.

Natural size.

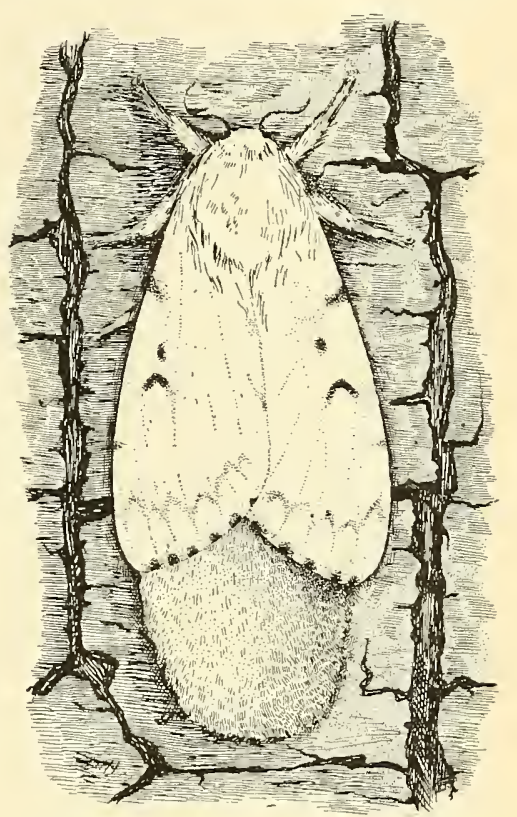

Figure 83. Female laying egg-cluster on bark of tree. Natural size.

but in Connecticut the average length is about an inch. Egg-clusters are shown in Figures 80 and 85.

Larva. The young larvae resemble the mature ones closely enough so that they may be easily recognized when seen. The fully grown caterpillar has a dusky ground color, finely marked with darker spots, giving it a granular appearance. Sometimes it has a marked brown tint, and sometimes it is decidedly gray. There is a lighter stripe along the back with a row of tubercles on each side of it, two on each segment. From the head, the first five pairs of tubercles are blue; the remaining six pairs are brick red. The colors show more prominently as the larvae approach maturity. There is usually a lighter lateral stripe between the row of tubercles and the spiracles. The ventral surface. legs and pro-legs are 
light grayish brown. The head is dark brown marked with yellow. Each segment bears six tubercles arranged in a transverse row, each tubercle bearing a tuft of hairs. The larvae vary from two to three inches in length and are shown on the cover and in Figure 81.

Pupa. The pupa is almost naked but is loosely inclosed by a few strands of silk. It is reddish brown in color with a few short, light brown hairs around the spiracles and across the thoracic and abdominal segments. The apical extremity by which it is fastened also bears a tuft of these hairs. The pupae usually occur in clusters in protected places, such as under fence rails near the posts, in crotches of trees, cavities, and similar locations. This stage is shown in Figures 80 and 82.

Adult. The female is dirty, creamy white with rather faint, transverse brown markings, and having a wingspread varying between two and two and one-half inches. The abdomen is heavy, cylindrical, and covered with

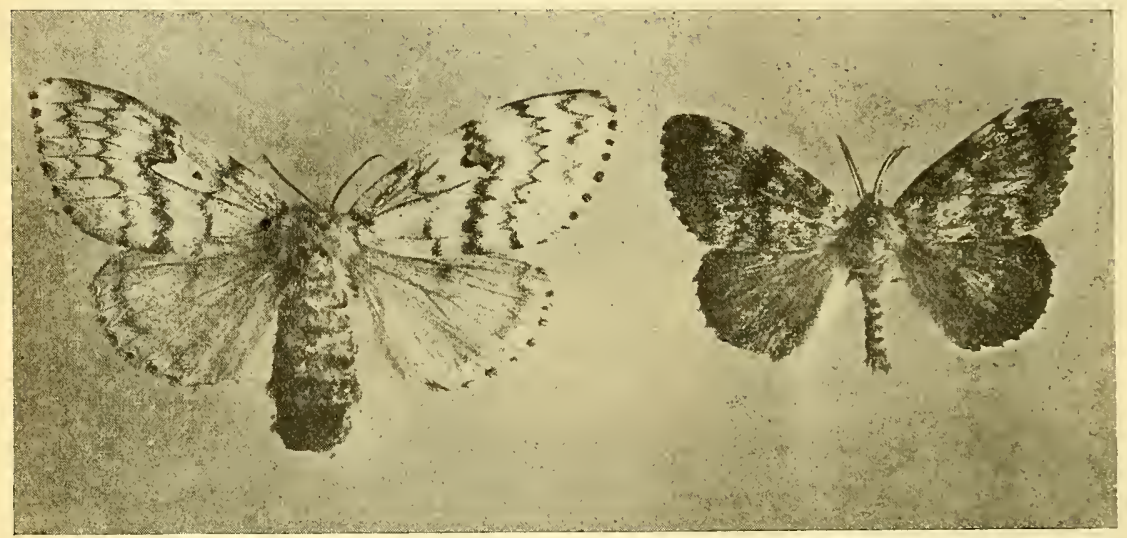

Figure 84. Female and male gypsy moths. Natural size.

buff hairs. The male is smaller and much darker in color. He has a wingspread of about one and one-half inches, with a small and pointed abdomen. The color is brown, varying considerably. Antennae in both sexes are pectinate, narrow and black in the fenale, broader and light brown in the male. The female is shown in Figure 83, and both sexes in Figure 84.

\section{NATURAL ENEMIES}

Every species of insect has its natural enemies. The gypsy moth has several which are native to this country, but none of them is effective in holding it in check. One of the large ground beetles, Calosoma scrutator Fabr., known as the "searcher" or "caterpillar hunter," was rather common under the burlap bands at Stonington and at Wallingford, and was observed eating the caterpillars. One of these beetles in captivity devoured 137 gypsy caterpillars in 13 days, an average of more than 10 per day. 


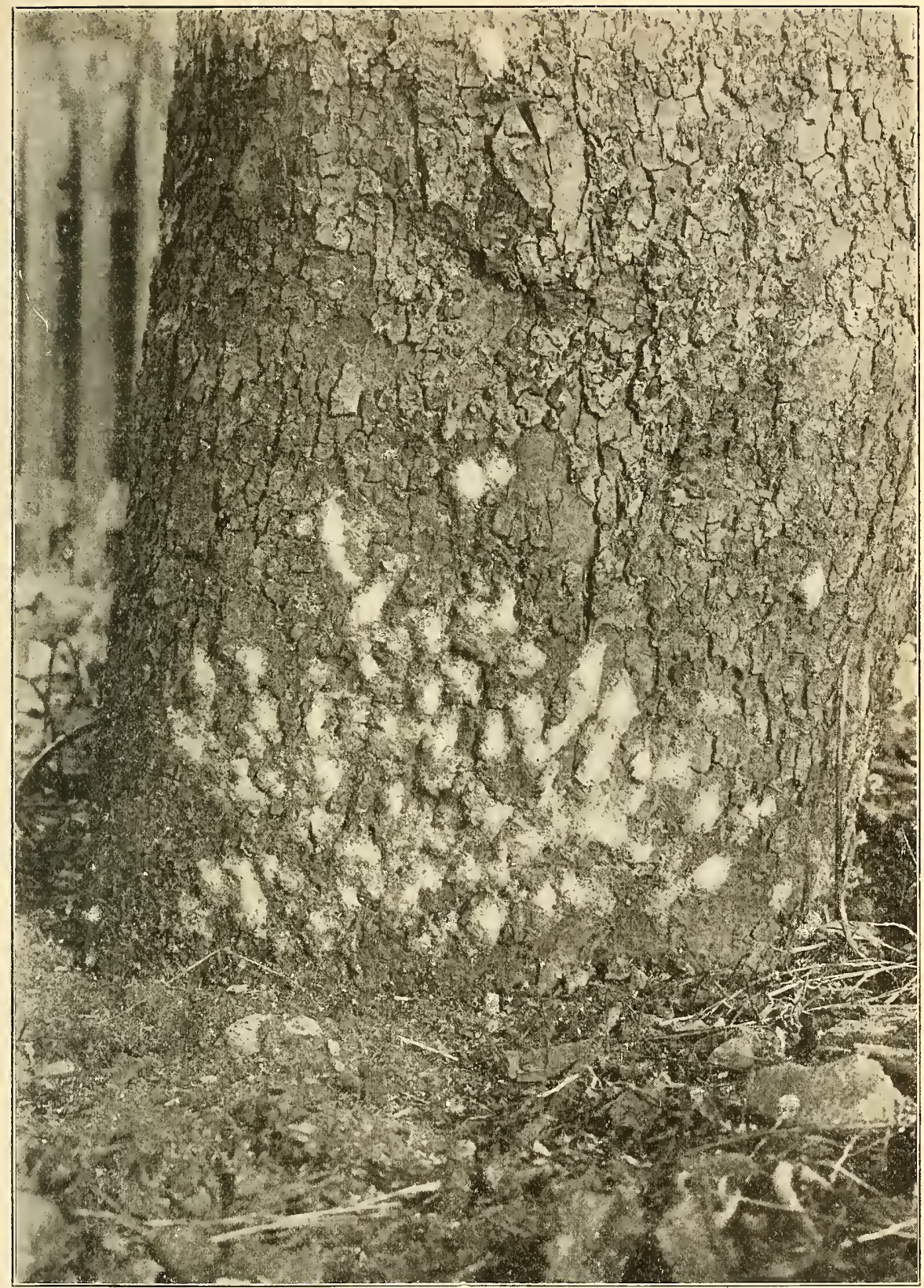

Figure 85. Egg-clusters on trunk of apple tree. 
Calosoma calidum and C. frigidum also feed upon the caterpillars, and no doubt other large ground beetles eat them also.

Several species of Dipterous parasites have been bred from gypsy caterpillars. In 1910, a caterpillar was observed at Wallingford with Tachinid eggs on its back. This caterpillar pupated in captivity, and from the pupa emerged a large, two-winged fly, Exorista larvarum Linn., (Tachina mella Walk.) (See Figure 87.) The gypsy moth pupa was closely packed with the puparia of the fly, but only one adult emerged. Several other Tachinid flies have been reared from the gypsy moth. Several Hymenopterous or four-winged parasitic flies have been recorded as attacking the gypsy moth. Three or four species of predaceous bugs, called "soldier bugs," are known to attack and kill the caterpillars.

Though upwards of 40 species of birds have been observed feeding upon the gypsy moth in its different stages, only a few species are useful in destroying the pest. Among these are the cuckoos, oriole, robin, catbird, blue jay, crow, chipping sparrow, chickadee and vireos.

A wilt disease which has been known for several years and which may be indigenous to this country, kills many caterpillars, but is more common where over-population exists or the food supply is depleted.

As mentioned above, all the native natural enemies occurring in New England have so far demonstrated their inability to control or appreciably to check the gypsy moth.

\section{IMPORTED PARASITES}

As has been stated, in Europe the gypsy moth is not such a destructive pest as in the United States, and probably is held in check by natural enemies. Beginning in 1905, the State of Massachusetts, in coöperation with the Federal Bureau of Entomology, sought to import some of the parasites and predaceous insects from abroad as an aid in controlling the pest in the United States. Dr. L. O. Howard, then Chief of the Bureau of Entomology at Washington, made several trips to Europe and enlisted the services of all the leading entomologists in countries where the gypsy moth occurs. Japan was visited for the same purpose.

Consequently, parasitized material was gathered in enormous quantities and sent to the Gypsy Moth Laboratory at Melrose Highlands, Mass., where the parasites were reared, segregated and studied. Manr species were found to be hyperparasites and had to be destroyed. The more promising primary parasites were reared in large numbers and were liberated in situations favorable for their development. This work has been continued ever since by the Federal Bureau of Entomology:

Altogether, more than three dozen species of parasites and predaceous insects have been introduced to check the gypsy moth and the brown-tail moth. Some of these insects were never recovered after they were liberated and some eked out a feeble existence. On the other hand, several species became established, multiplied rapidly and have successfully passed a number of New England winters. Colonies of sereral of these species have been liberated in Connecticut. 
Among the most important of the introduced natural enemies is a large, purplish, iridescent ground beetle, Calosoma sycophanta Linn., shown in Figure 86. This beetle comes from Europe, and in both its adult and larval stages feeds upon the caterpillars and pupae of the gypsy moth. Colonies were liberated in Stonington in 1914, and in Thompson in 1915. In May, 1915, Mr. Harry L. Johnson took a specimen near his house in South Meriden, at least 40 miles distant from the nearest point of liberation. Collections and observations made at various times and places during the past 20 years indicate that this beetle is present in Connecticut and each year kills a certain percentage of the larvae and pupae of the gypsy moth.

Two species of Diptera or two-winged flies from Europe are effective parasites. Compsilura concinnata Meig. attacks the large caterpillars and

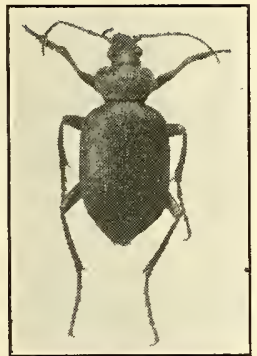

Figure 86. European calosoma, Calosoma sycophanta. Natural size.

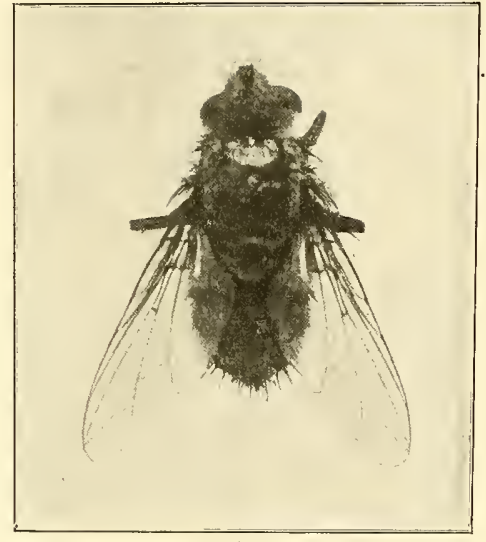

Frgure 87. A native Tachinid fly Exorista larvarum reared from a gypsy moth pupa at Wallingford. Three times enlarged.

Sturmia scutcllata Rob.-Desv., the pupae. The former was liberated at various points in eastern Connecticut, and at Hartford and Suffield, west of the Connecticut River, during the period from 1912 to 1917. In certain localities in 1932, this species parasitized more than 40 per cent of the larger larvae, and has an average record of 22.5 per cent for the past six years.

The latter (Sturmia scutellata, formerly listed as Blepharipa scutellata) was first colonized in Connecticut at Coventry and North Stonington in 1922. In 1929 and 1930 it destroyed nearly one-third of the gypsy moth pupae in certain localities. Since then it has been less effective but has an average record of 14.6 per cent for the past six years. .

Perhaps the most important group of introduced parasites are the Hymenoptera or four-winged parasitic flies. Two of these are egg parasites. One from Europe, Anastatus disparis Ruschka, formerly listed as 
Anastatus bifasciatus Fonsc., has been liberated in Connecticut in large numbers as follows:

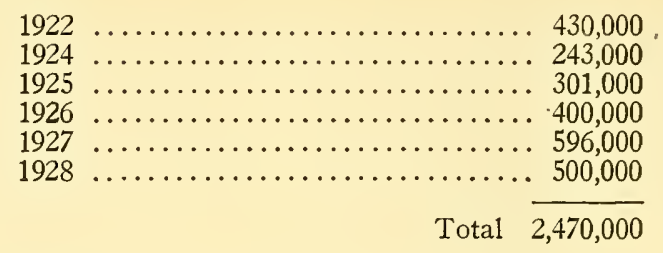

This species is regarded as the more important of the egg parasites, and in certain seasons may parasitize about 10 per cent of the eggs in some localities.

The other egg parasite from Japan, Ooencyrtus kuvanae Howard (formerly known as Schedius kuvanae) was considered promising and in certain seasons large numbers were liberated in Connecticut as follows:

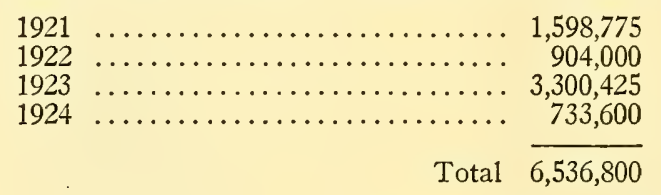

According to Mr. C. W. Collins of the Gypsy Moth Laboratory, this Japanese egg parasite of the gypsy moth has not been of much importance in recent years. It was more effective in southeastern Massachusetts and Rhode Island than elsewhere, but even here, of the eggs collected during the past six years, fewer than 10 per cent have been destroyed by it.

Perhaps more important than the Japanese egg parasite is Apanteles melanoscelus Ratz., from southern Europe, which parasitizes gypsy moth caterpillars. It has been liberated in Connecticut as follows:

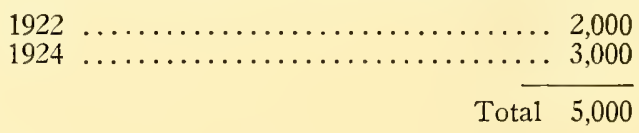

In 1930, A. melanoscelus parasitized about 11 per cent of the small caterpillars at Thompson, but the scarcity of this parasite for each of the four years since 1930, reduces the average to less than 2 per cent.

These percentage records of parasites were mostly obtained through the courtesy of Mr. Collins, in charge of the above-mentioned laboratory, from collections made by Mr. J. T. Ashworth and his men in Thompson, Conn., where a more or less stable, light, general infestation has prevailed for several years. Thompson is also one of the localities in or near which nearly all of these species of parasites have been liberated.

Nevertheless, the combined efforts of both native and introduced parasites and natural enemies have not been sufficient to prevent the gypsy moth from defoliating trees over large areas. Creosoting egg-clusters and spraying are necessary to hold it in check. 


\section{PREVENTION OF SPREAD}

\section{Barrier Zone}

At a conference at Albany, November 16, 1922, resolutions were adopted urging that a control zone be established and maintained between Long Island Sound and the Canadian border. Such a zone was soon established and has since been maintained.

In general, it is about 30 miles in width, includes Lake Champlain, and follows the Hudson River as its western boundary, but is somewhat shortened by cutting across toward the east, through Connecticut. Approximately half of the area of this zone is in New York State and the other half, equivalent to a strip two or three towns wide, is in New England, as shown in Figure 88. This is called the "barrier zone".

Extraordinarily thorough scouting work has been done in the zone and repeated each year. Although infestations have been found there, they have been eradicated at once. No infestation is allowed to exist within the barrier zone. Likewise, west of and adjacent to the zone, New York scouts go over the territory very carefully and eradicate each infestation. To the east, both federal and state workers have paid special attention to scouting, even to the neglect of the infested towns in the eastern end of the State. These efforts, of course, are all directed toward preventing the westward spread of the pest, which would endanger the whole country. Altogether, this barrier zone plan is one of the very best schemes for the purpose that has ever been proposed.

\section{Quarantine Restrictions}

Although the first federal gypsy moth quarantine was established and became effective August 1, 1913, no towns in this State were included. Revised in 1914, it named 10 towns in eastern Connecticut, and in 1915, 20 towns. This quarantine was revised from year to year, sometimes including additional towns and sometimes releasing those in which no infestations could be found by the scouts.

The first state quarantine, established in 1920, placed restrictions on 21 towns in the eastern end of Connecticut; in 1921, 27 towns. In 1922, so many towns had become infested by windspread that 94 were restricted by state and federal quarantine, including the whole of Windham County (15 towns); Tolland County, 13 towns; in New London County, 19 towns; 4 towns in Middlesex County, 2 towns in New Haven County, 29 towns in Hartford County and 12 towns in Litchfield County.

In 1924, 118 towns were quarantined, the increase being chiefly in Litchfield, Middlesex and New Haven counties. This area contained all of the towns that are now under quarantine and several that have since been released. Since that time, due chiefly to the establishment and strict maintenance of the barrier zone, there have been few changes, except to divide the infested area into two zones, known as generally infested and lightly infested.

This division was first made in 1926, and has been revised several times, usually by subtracting from the lightly infested and adding to the generally infested zone. At the time of this writing (1935) there are 


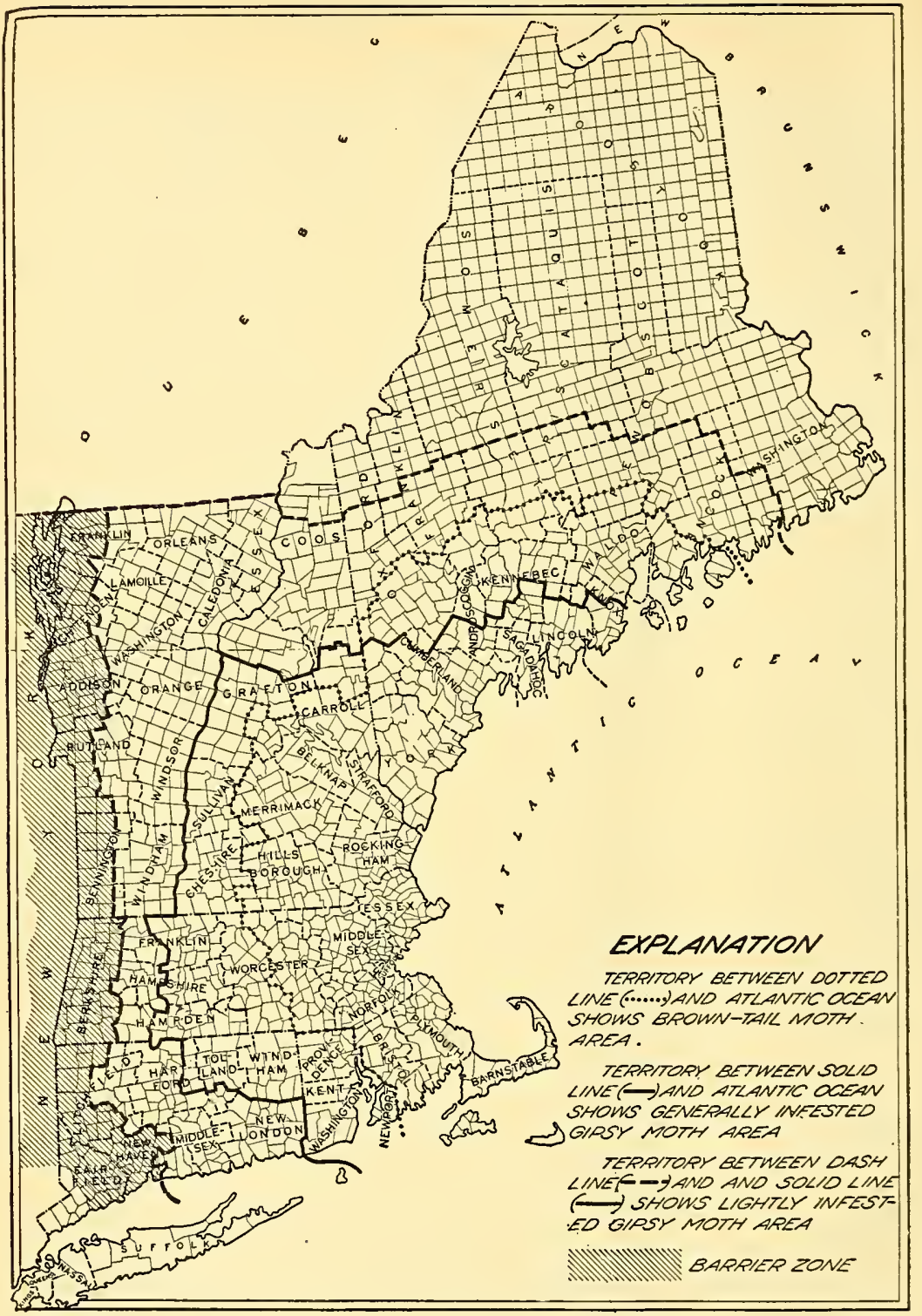

Figure 88. This map of the New England States shows the barrier zone, and the generally and lightly infested gypsy moth areas (After Federal Horticultural Board, U. S. Dept. of Agriculture). 
109 towns under quarantine regulation in Connecticut, 64 in the generally infested and 45 in the lightly infested zone. This leaves 60 towns free from quarantine. These areas are shown on the map, Figure 89.

All woody plants, also logs, poles, lumber, cordwood and other forest products, brick, stone and quarry products, can be shipped out of either the generally or lightly infested areas into the free area only after inspection and with state or federal certificate. Christmas trees and Christmas greens originating in the generally infested zone are not permitted to be shipped out of that zone, but such materials grown in the lightly infested zone will be inspected, certified and their movement allowed into the free area.

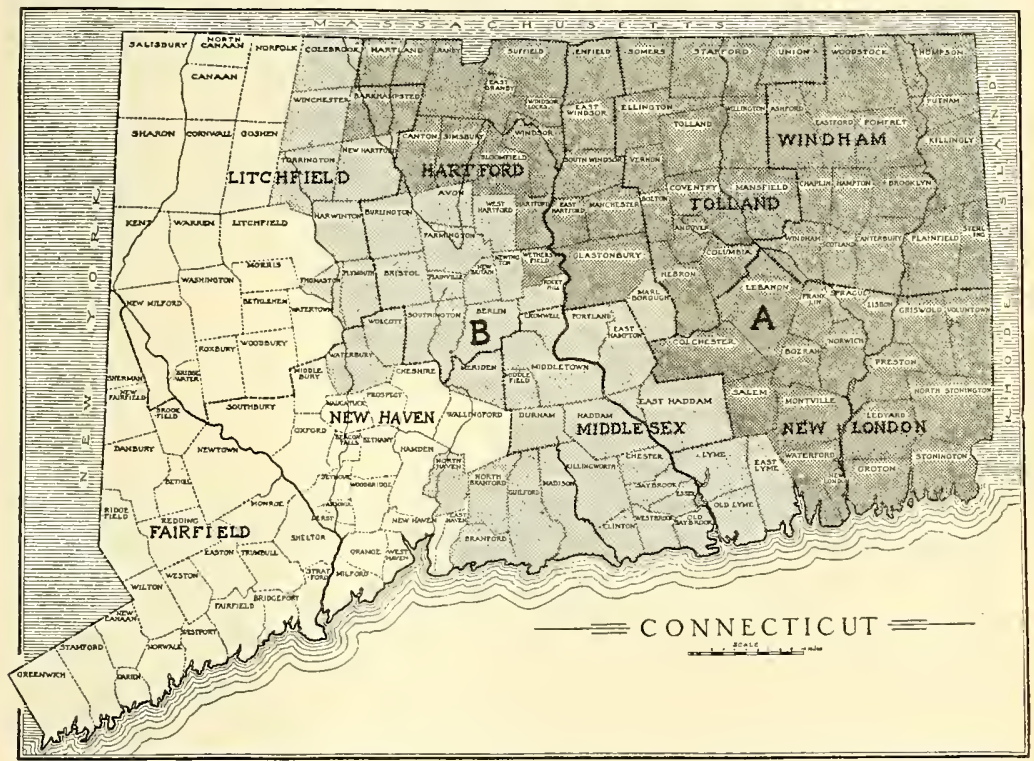

Figure 89. Map of Connecticut showing areas regulated by federal and state quarantines, tecause of the gypsy moth. A, Generally

infested; B, lightly infested.

\section{CONTROL MEASURES}

Scouting and Creosoting Egg-Clusters. Scouting can best be carried on when the trees are bare. Scouts are organized into crews of four men and a foreman. Each foreman has a map of the town showing all roads. Roadside scouting is the system commonly practiced and consists of examining the trees in the open country, particularly around human habitations, and in wooded areas a strip 100 feet wide along the road. If the region is thought to be lightly infested, particular attention is paid to oak and apple trees which are preferred by the caterpillars. In regions heavily or generally infested, the scouts examine all trees between roads. In woodland scouting, each scout covers a strip about 15 feet wide and 


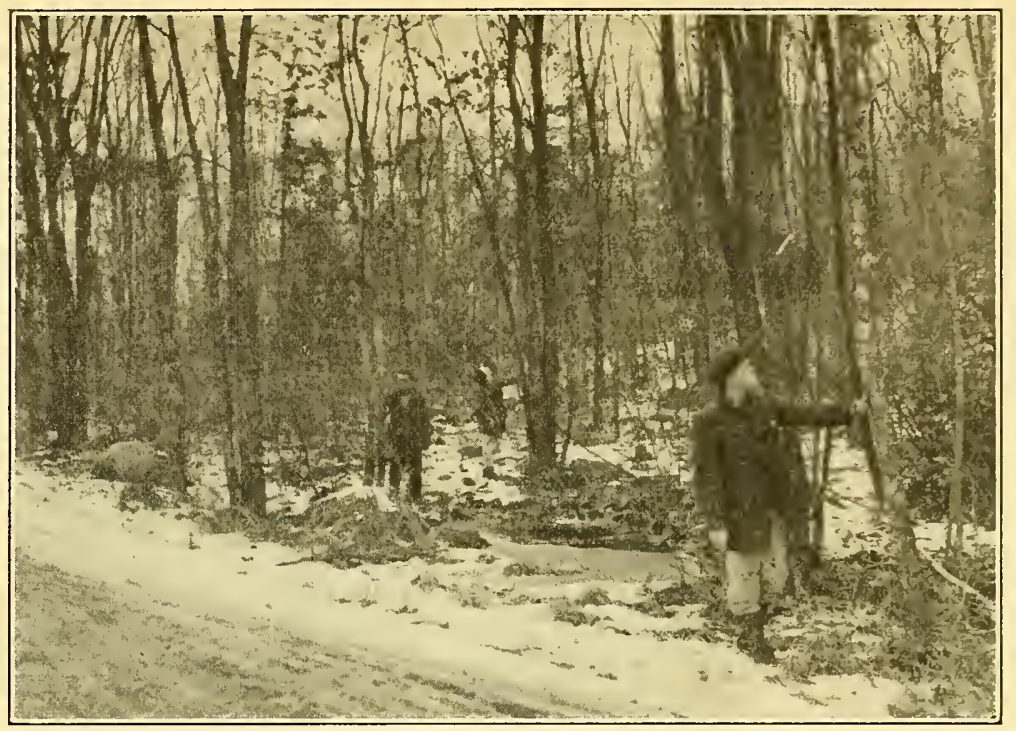

FIGURE 90. These men are scouting in a woodland at Thompson.

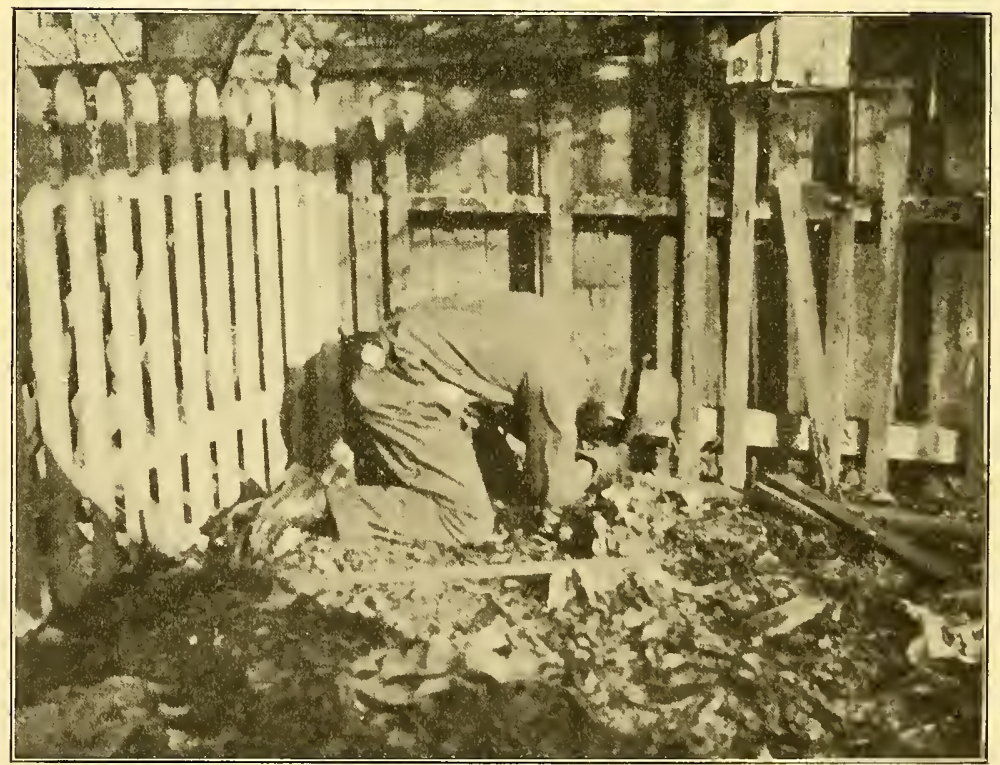

FIGURE 91. The scouts examining fences and destroying egg-clusters. 
the crew begins on one side and moves back and forth through the woodland until the area is finished.

In case an infestation is discovered, much time is spent in making a very careful examination to determine its size and limits.

Each scout has an identifying mark that he scratches in the outer bark of each tree that he examines. No two marks are alike, and if the foreman finds an egg-cluster that has been overlooked, he knows at once who was responsible for missing it. On choice fruit, shade and ornamental trees where scratches might be objectionable, chalk marks are used. The foreman inspects a portion of the trees examined by each scout and likewise places his mark upon them, thus sharing in the responsibility. Some of the most common marks used are $\neg \mathrm{L} \vee \wedge$ and $X$. Figure 90 shows a scouting crew at work.

Infestations are usually indicated by figures painted on trees or fence posts along the roadsides, as near as possible to the infestation or to some convenient point of entrance. The figures show the year discovered, the number of trees infested and the number of egg-clusters. Example: $35 / 8$ indicates that in 1935 eight trees were found infested with 194 eggclusters. Usually an arrow shows the direction of the colony from the highway.

All egg-clusters are soaked with creosote to kill the eggs. The addition of lamp black to the creosote discolors or darkens the egg-clusters so that it is possible to distinguish them from untreated clusters.

Banding Trees. In certain infestations where spraying is impracticable, burlap bands are often placed around the trunks of the trees as an aid in finding caterpillars in case the eggs have not all been destroyed. The caterpillars feed at night and crawl underneath the bands or into some other protected place to remain during the day. These bands are examined frequently during the caterpillar season and all caterpillars are killed. In connection with infestations on hill tops or other exposed situations, where there is danger of windspread, and where there may have been eggs on the ground, sticky bands of "tree tanglefoot", or other tree banding material, are placed around the trunks of trees to prevent the little caterpillars from going up to feed. As with the burlap bands, these sticky bands are examined frequently. All caterpillars found are killed and a record is kept of the number. Figure 92 shows the method of applying a burlap band.

Cutting Brush. In some heavy infestations it is necessary to cut and burn the brush to make roads or lanes preparatory to spraying. It is desirable to be able to drive the power sprayer into or near the infestation, and in order to handle the hose, avenues free of brush are necessary. Where there are swamps, ledgy or rough ground over which the sprayer cannot be driven, sometimes several thousand feet of hose must be used to reach the infested trees.

Spraying. In average seasons, spraying operations may be started soon after the middle of May, or when the leaves and caterpillars are about 
half-grown. In 1935 the season was late. Spraying was commenced May 23.

Arrangements to obtain water must be made in advance. Spray materials and hose are carried on the sprayer or on separate trucks.

The poison now most commonly used and recommended for gypsy moth spraying is lead arsenate at the rate of at least 5 pounds in 100 gallons of water. Sometimes a spreader or sticker is desirable. Skim milk powder may be used in this capacity. Stickers are not considered safe to use where cattle may browse upon the foliage. Fish oil makes a good adherent

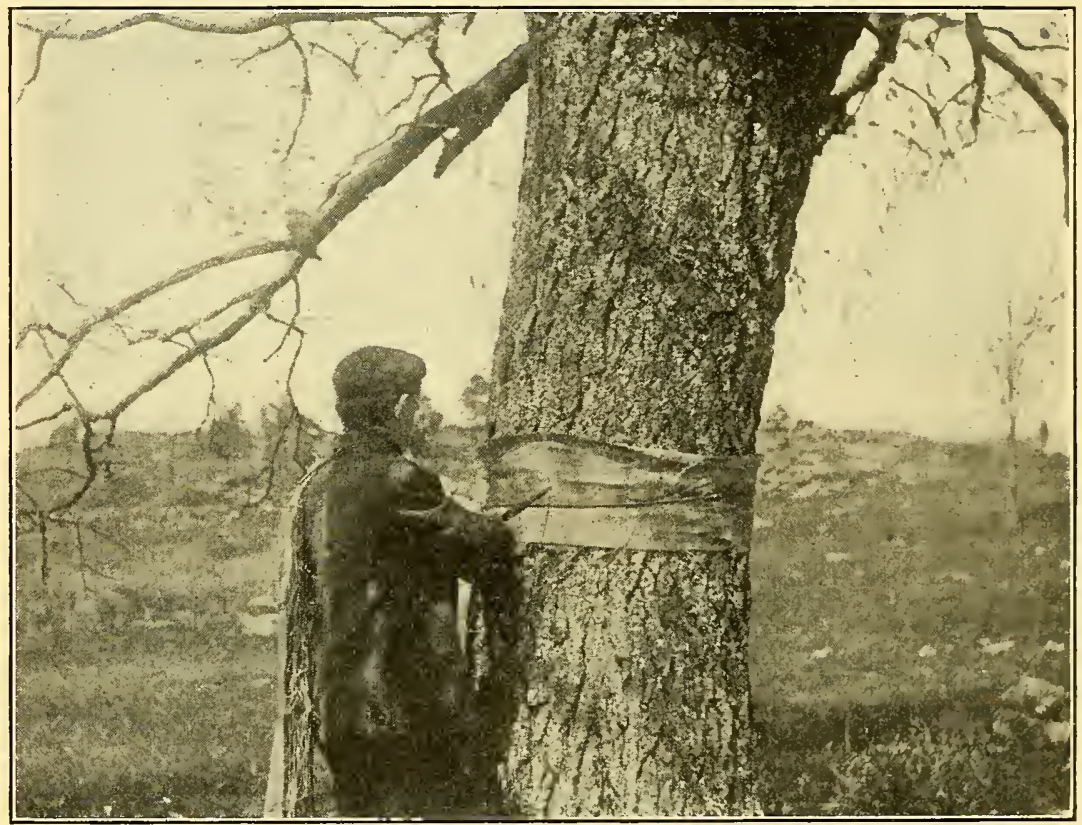

Figure 92. This is the method of applying a burlap band, one of the control measures.

or sticker but, on account of its odor, it is objectionable on trees near residences. In forest infestations or on trees in the open country, it can be used and makes an excellent and inexpensive sticker. Linseed oil or skim milk powder may be used around premises where an adherent is desired.

The formula for gypsy moth spray is as follows:

Lead arsenate powder ........... 5 lbs.

Fish oil or linseed oil (sticker)* ${ }^{*} \ldots 11 / 2$ pts.

Water ................... 100 gals.

In gypsy moth spraying a solid stream is thrown through a special nozzle from the ground into the tops of the tallest trees, where it breaks into a spray and drifts with the wind through the tree tops and over the foliage beneath, as shown in Figure 93. For this purpose powerful pumps

*Skim milk powder (1 lb.) may be substituted for the oils. 
are necessary, and 300 pounds pressure at the nozzle is required. A much higher pressure at the engine is essential because pressure is greatly reduced by friction in passing through long lines of hose. The present power sprayer outfits used in Connecticut, shown in Figure 94, will deliver 1,000 pounds working pressure at the engine.

Usually spraying stops between the middle of June and July 4, or when the caterpillars have nearly reached maturity and some of them begin to pupate.

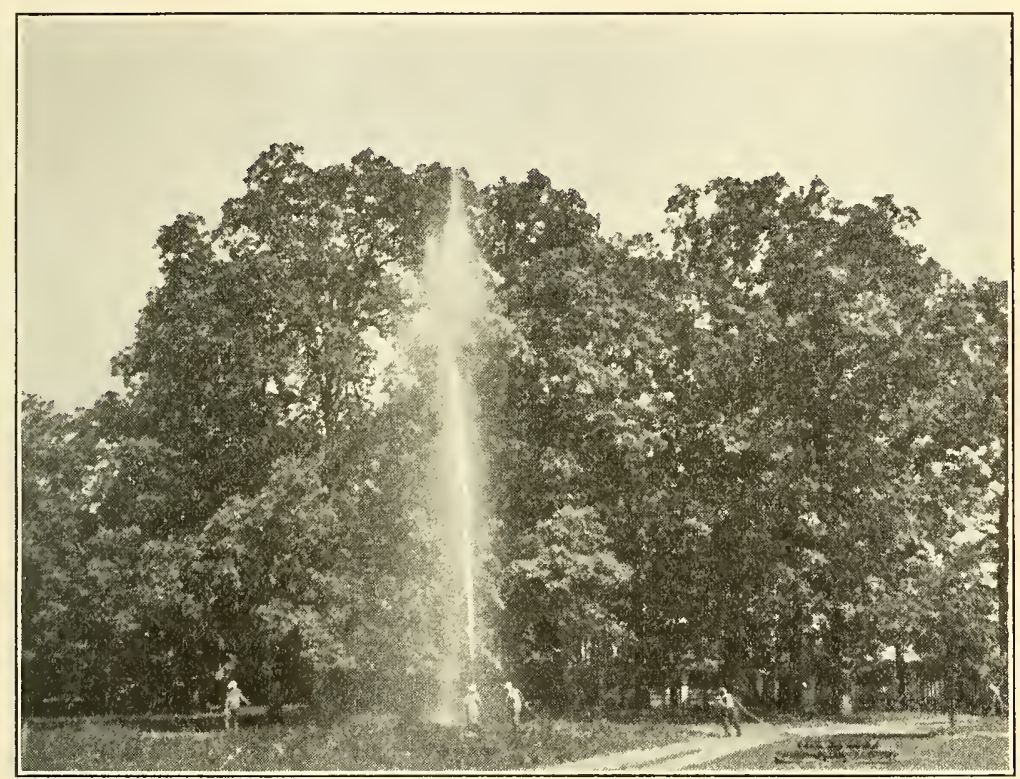

FIGURE 93. The attomobile truck power sprayer is powerful enough to send the spray into the tree tops.

\section{SUMMARY}

Distribution and Spread. The gypsy moth occurs in central and southern Europe, northern Africa and Asia. It was brought into eastern Massachusetts about 1869 in an attempt to cross it with silk worms to produce a hardier race of the latter. Some escaped from the breeding cages in Medford, and 20 years later the insect became such a pest that the town, and later the State, appropriated funds for its suppression.

State work was kept up for 10 years, but was discontinued in 1900. In 1905, suppression measures were resumed by the State, after the pest had spread over more than six times the area formerly infested. The first congressional appropriation for the control of the gypsy moth was made in 1906, and since then the Federal Government has coopperated with the infested states in this work. Altogether, more than $\$ 41,000,000$ of state and federal funds have been expended. 
The infested area in New England now includes the eastern two-thirds of Connecticut, all of Rhode Island, all of Massachusetts except Berkshire County, the southwestern third of Maine, all of New Hampshire except the northernmost portion, and the eastern part of Vermont, somewhat less than half the State, the extreme northern counties not being infested. The infested areas in Connecticut are shown on the quarantine map, Figure 89.

Many isolated infestations have been discovered and eradicated in New England and outside, particularly in New York, Pennsylvania, New Jersey and Ohio. A large area is now being treated in Pennsylvania.

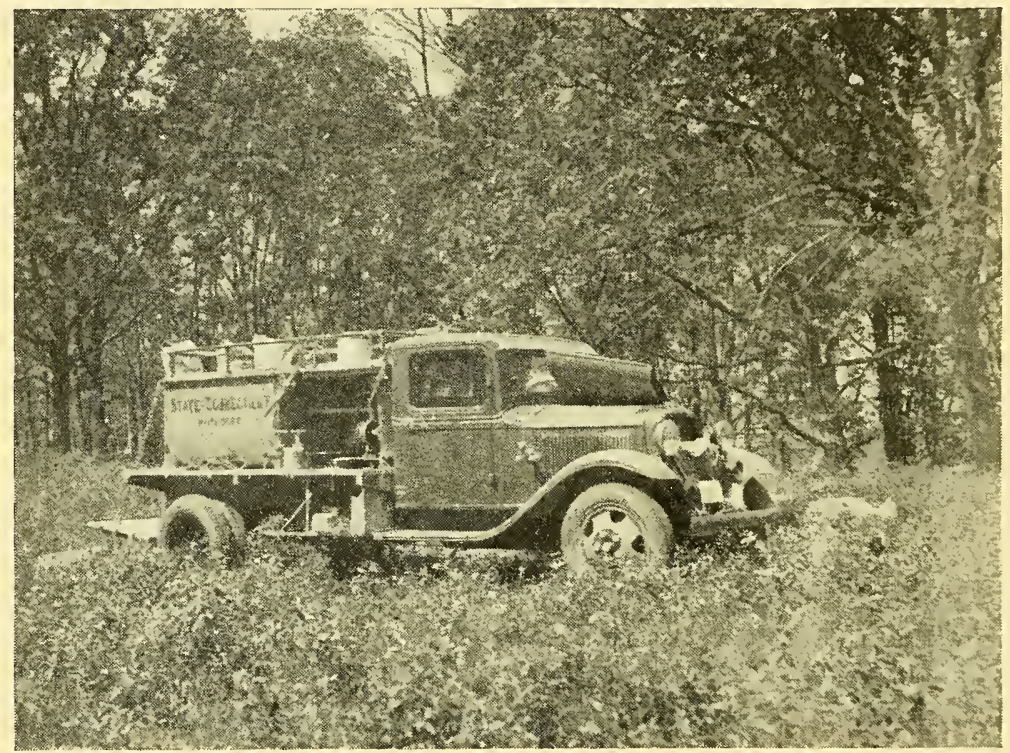

FIgURE 94. This new Fitzhenry-Guptill power sprayer with Ford chassis supplies $1000 \mathrm{lbs}$. pressure at the engine.

Methods of Spread. The gypsy moth may be spread as follows: Eggclusters on shipments of quarry and forest products, nursery stock, packing crates and the like; caterpillars and pupae on vehicles; newly hatched caterpillars are blown about in a strong wind. Transportation was probably responsible for most of the isolated colonies, and windspread has increased the area of the long-standing infestations.

Life History. Egg-clusters laid in stmmer hatch the following spring, and the caterpillars become fully grown about the first of July. They then go into protected places and transform to the pupa stage. From 10 to 14 days later, the adults emerge.

The female is a large-bodied, whitish moth, with wingspread of more than two inches. She cannot fly but lays on tree, fence, wall or building, masses covered with buff-colored hair, containing 400 or more globular eggs. The male is smaller and darker in color and flies about. The mature 
caterpillars are between two and three inches long, dark gray or brown, and hairy. A narrow light stripe extends along the back, with a row of tubercles on each side. Each tubercle bears light brown hairs. From the head backward, the first five pairs of tubercles are blue and the remaining six pairs, brick red. The chrysalis is a naked brown pupa fastened loosely by a few strands of silk.

Natural Enemies. Native birds such as cuckoos, oriole, robin, vireos, etc., feed upon the caterpillars. In heavy infestations, the wilt disease often kills large numbers. There are several predaceous insects, including the large ground beetles and the "soldier bugs," which destroy limited numbers, and a few native two-winged and four-winged flies are parasites. All insect enemies of the gypsy moth that can be found throughout its range have been brought from the Old World to New England. Of these, a large ground beetle, Calosoma sycophanta; two Tachinid flies, Compsilura concimnata, and Sturmia scutellata; a four-winged larval parasite, Apanteles melanoscelus, and a minute four-winged egg parasite, Anastatus disparis, at present seem to be the more promising. All of these agencies together do not keep the pest in check.

Food Plants and Damage. The gypsy caterpillars, when large, feed upon nearly all kinds of vegetation, the ash perhaps being the most nearly immune of all the deciduous trees. Even conifers, which soon die if defoliated, are fed upon by the larger caterpillars, but the newly hatched caterpillars require some other food.

Large woodland areas in Massachusetts, Maine and New Hampshire, and small areas in Connecticut have been defoliated and many acres of trees have been killed by the caterpillars.

Barrier Zone. The barrier zone is a strip about 30 miles (more or less) in width, extending from the Canadian border to Long Island Sound, and shown in Figure 88. This zone is thoroughly exanined each year and all infestations eradicated.

Quarantines. State and federal quarantines now cover the New England infested area in two zones: (1) Generally infested, (2) lightly infested. All forest and quarry products and nursery stock from the generally infested area into the lightly infested area, or from either area to points outside, must first be inspected and bear an inspection certificate. These quarantined areas in Connecticut are shown in Figure 89.

Control Measures. The chief control measures are: Scouting and creosoting egg-clusters; cutting and burning brush in some infestations; banding trees with burlap or tanglefoot and killing caterpillars and pupae in certain infestations; spraying the more important infestations with lead arsenate, 5 pounds in 100 gallons of water. 
5389 



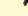

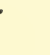


University of

Connecticut

Libraries 


\section{(y-3)}

(4)

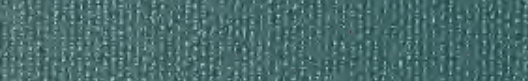

